Sanadi, D. R. \& Littlefield, J. W. (1951). J.biol. Chem. 193, Warburg, O. \& Christian, W. (1938a). Biochem. Z. 296, 683.

Schrecker, A. W. \& Kornberg, A. (1950). J. biol. Chem. 182, 795. 294.

inger, T. P. \& Kearney, E. B. (1950). Arch. Biochem. 27, 348.

Stadie, W. C. \& Zapp, J. A. (1943). J. biol. Chem. 150, 165.

Warburg, O. \& Christian, W. (1938b). Biochem. Z. 298, 150, 377.

Weber, G. (1950). Biochem. J. 47, 114.

Whitby, L. G. (1950). Nature, Lond., 166, 479.

Whitby, L. G. (1952). Biochem. J. 50, 435.

\title{
The Inhibition of Erythrocyte Cholinesterase by Tri-esters of Phosphoric Acid
}

\section{THE NATURE OF THE INHIBITORY PROCESS}

\author{
BY W. N. ALDRIDGE \\ Medical Research Council Unit for Research in Toxicology, Serum Research Institute, \\ Carshalton, Surrey
}

(Received 11 October 1952)

The inhibition of cholinesterase by organophosphorus compounds has been called irreversible inhibition. However, it has become clear that in vivo there are differences in the rate of return of cholinesterase after tetraethyl pyrophosphate (TEPP), diisopropyl phosphonofluoridate (diisopropyl fluorophosphonate, DFP) (Dayrit, Manry \& Seevens, 1948; Hobbiger, 1951) and after $N N^{\prime}$-diisopropylphosphorodiamidic fluoride (bisisopropylaminofluorophosphine oxide; Isopestox) (Callaway, Davies \& Risley, 1952). By experiments in vitro it has been demonstrated that the inhibition of cholinesterase by TEPP is slowly reversible (Hobbiger, 1951; Wilson, 1951). If the inhibitory process is a phosphorylation of the enzyme then the stability of the enzyme phosphate should be dependent upon the other groups attached to the phosphorus. On this basis the enzyme inhibited by dimethyl $p$-nitrophenyl phosphate should be more unstable than that inhibited by the diethyl analogue (E 600). In this paper this is confirmed and the process of reversal of inhibition after dimethyl $p$-nitrophenyl phosphate has been shown to be consistent with a reaction involving a dephosphorylation and not with a simple reversal of the inhibitory process. Burgen \& Hobbiger (1951) have also shown that the inhibition of cholinesterase by $m$ (dimethylphosphate) $N$-trimethylanilinium methyl phosphate is reversible but attributed this to a failure of the inhibitor to phosphorylate the enzyme.

An examination has also been made of the effect of temperature on the rate of inhibition of cholinesterase by $\mathrm{E} 600$. These results show that the inhibitory process has a high activation energy and is not a simple adsorption process. These observations and the work of others on the reactions of organo. phosphorus compounds are discussed and a mechanism is put forward which would explain both inhibition and reversal. This is similar to that postulated by Wilson, Bergmann \& Nachmansohn (1950) for the hydrolysis of acetylcholine which is presumably the natural substrate for this enzyme.

\section{EXPERIMENTAL}

\section{Methods and Materials}

Cholinesterase has been determined as previously described in detail (Aldridge \& Davison, 1952 a). Normally the buffer contains $0.0357 \mathrm{M}-\mathrm{NaHCO}_{3}, 0.164 \mathrm{M}-\mathrm{NaCl}$ and $0.040 \mathrm{M}$ $\mathrm{MgCl}_{2}$ but in some experiments the $\mathrm{MgCl}_{2}$ has been omitted. Rabbit blood was usually obtained from an ether-anaesthetized rabbit by cannulation of the carotid artery and bleeding out. Citrate was the anti-coagulant and the blood was stored at $5^{\circ}$.

A preparation of A-esterase (Aldridge, 1953a), which will hydrolyse dialkyl $p$-nitrophenyl phosphate inhibitors but which is free from cholinesterase activity, may be prepared by adding $1 \mathrm{ml}$. of approx. $10^{-4} \mathrm{M}$-DFP to $10 \mathrm{ml}$. citrated rabbit plasma or serum. The solution is then incubated for $1 \mathrm{hr}$. at $37^{\circ}$ and stored at $+5^{\circ}$. The excess DFP is rapidly removed by rabbit serum (Mazur, 1946; also cf. Table 2) and the inhibition of the cholinesterase by DFP is not measurably reversible for many weeks under these conditions.

It should be noted that after inhibition of rabbit erythrocyte cholinesterase by dimethyl $p$-nitrophenyl phosphate the inhibition is stopped upon the addition of substrate and the enzyme activity is returning throughout its determination. Although in these circumstances the output of $\mathrm{CO}_{2}$ is not linear with respect to time, the best straight line through these points (Aldridge, Berry \& Davies, 1949) has been calculated and the slope used as a measure of the activity over the period of determination. 


\section{Technique for studying reversal of inhibition}

In order to examine the rate of reversal of inhibited cholinesterase in vitro it is necessary after inhibition to remove excess inhibitor. If this is not done any of the original enzyme which reappears will be inhibited again. The inhibitors used in this study are relatively stable and little will be removed by aqueous hydrolysis only (Table 1).

\section{Table 1. The rate of hydrolysis of inhibitor}

(Rates of hydrolysis were determined in Sørensen's $0.0667 \mathrm{M}$-phosphate buffer, $\mathrm{pH} \mathrm{7.6}$, at $37^{\circ}$. The liberated $p$-nitrophenol was determined colorimetrically at $398 \mathrm{~m} \mu$. using the Unicam quartz spectrophotometer.)

$\begin{array}{ccc}\text { Inhibitor } & \begin{array}{c}\text { First-order } \\ \text { rate constant } \\ \left(\mathrm{hr} .^{-1}\right)\end{array} & \begin{array}{c}\text { Half-life } \\ (\mathrm{hr} .)\end{array} \\ \begin{array}{c}\text { Dimethyl } p \text {-nitrophenyl } \\ \text { phosphate }\end{array} & 1.6 \times 10^{-2} & 44 \\ \begin{array}{c}\text { Diethyl } p \text {-nitrophenyl } \\ \text { phosphate }\end{array} & 2.9 \times 10^{-3} & 233 \\ \begin{array}{c}\text { Diisopropyl } p \text {-nitrophenyl } \\ \text { phosphate }\end{array} & <10^{-4} & >7000\end{array}$

Table 2. Rate of hydrolysis of inhibitors by rabbit serum

(Buffer used contained 0.0357 $\mathrm{M}-\mathrm{NaHCO}_{3}, 0 \cdot 164 \mathrm{M}-\mathrm{NaCl}$ and gelatin $(0.1 \%, w / v)$. Substrates were prepared by dissolving approx. $40 \mathrm{mg}$. inhibitor in $0.5 \mathrm{ml}$. methanol, blowing into $25 \mathrm{ml}$. buffer and shaking vigorously to produce a fine dispersion. Results are corrected for nonenzymic hydrolysis.)

\section{Inhibitor}

Dimethyl $p$-nitrophenyl phosphate Diethyl $p$-nitrophenyl phosphate Diisopropyl $p$-nitrophenyl phosphate Diisopropyl phosphonofluoridate

$\mathrm{CO}_{\mathbf{2}}$ output
$(\mu \mathrm{l} . / \mathrm{ml} . / \mathrm{min}$.
$\mathbf{4 2 \cdot 5}$
$\mathbf{8 8 \cdot 0}$
$\mathbf{0}$
$\mathbf{5 6}$

\section{Table 3. Effect of constituents of buffer on the hydrolysis of $E \mathbf{E 0 0}$ by rabbit serum}

(Buffer constituents are used at the following concentrations; $0.0357 \mathrm{M}-\mathrm{NaHCO}_{3} ; 0.164 \mathrm{M}-\mathrm{NaCl} ; 0.04 \mathrm{M}-\mathrm{MgCl}_{2}$; $0 \cdot 1 \%, w / v$, gelatin. Substrate suspensions were prepared as described in Table 2;0.5 ml. 1/5 rabbit serum was used for each experiment.)

\begin{tabular}{lc}
\multicolumn{1}{c}{ Buffer constituents } & $\mathrm{CO}_{2}$ output \\
$(\mu \mathrm{l} / \mathrm{ml} /$ min. $)$
\end{tabular}

However rabbit serum contains an enzyme, A-esterase, which will hydrolyse E600 (Aldridge, 1953 $a$ ) and Table 2 shows that it will also hydrolyse dimethyl $p$-nitrophenyl phosphate. Rabbit erythrocytes contain true cholinesterase and almost all of the activity of the serum against acetylcholine is due to true cholinesterase (Mendel \& Rudney, 1945; Levine, Hoyt \& Suran, 1950). Rabbit whole blood may therefore be used as a source of the cholinesterase when acetylcholine is the substrate. After inhibition by dimethyl $p$-nitrophenyl phosphate or E600 the excess of inhibitor is rapidly removed leaving a preparation of inhibited enzyme for study. It has been found that the rate of removal of inhibitors is much reduced when using buffers containing magnesium. This is due to the inhibition of A-esterase by magnesium (Table 3). Therefore, for experiments in which a rapid removal of inhibitor is required, $\mathrm{MgCl}_{2}$ has been omitted from the buffer. This omission lowers the activity of cholinesterase by only $5-10 \%$.

\section{RESULTS}

$A$ comparison of the inhibition of cholinesterase by $E 600$ and dimethyl p-nitrophenyl phosphate. It has been shown previously (Aldridge, 1950; Aldridge \& Davison, 1952a) that the rate of inhibition of goat and sheep erythrocyte cholinesterase by E600 follows first-order kinetics. Fig. 1 shows that this

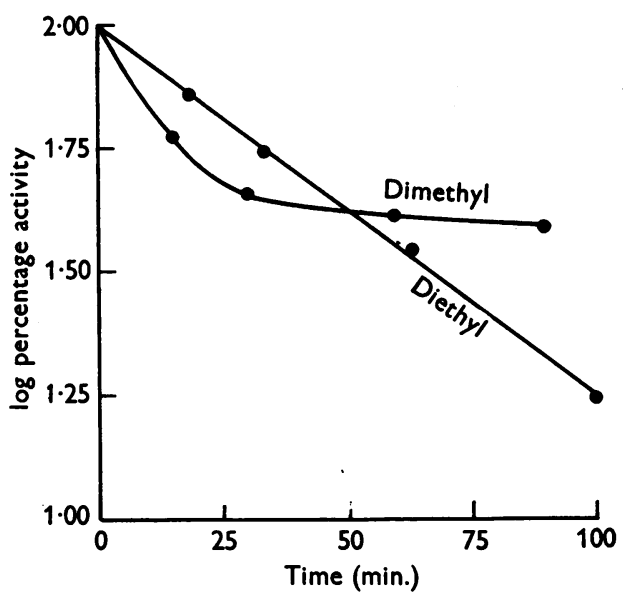

Fig. 1. Inhibition of rabbit erythrocyte cholinesterase by dimethyl and diethyl $p$-nitrophenyl phosphates. Concentrations of inhibitor: dimethyl, $4.2 \times 10^{-8} \mathrm{M}$; diethyl, $6.8 \times 10^{-9} \mathrm{M}$. Washed rabbit erythrocytes incubated with inhibitor at $37^{\circ}$. At various times acetylcholine was tipped in and activity determined. Buffer used contained $\mathrm{NaCl}, \mathrm{NaHCO}_{3}$ and $\mathrm{MgCl}_{2}$.

is also true when rabbit erythrocytes are used. However, when rabbit erythrocytes are inhibited by dimethyl $p$-nitrophenyl phosphate the reaction gradually reaches an equilibrium. This could be due to removal of inhibitor but when the suspending fluid was examined $90 \mathrm{~min}$. after addition of dimethyl $p$-nitrophenyl phosphate its inhibitory power was the same as at the beginning of the experiment. By using rabbit whole blood as the source of cholinesterase, it is possible to have conditions where the excess inhibitor is rapidly removed. Fig. 2 shows that $20 \mathrm{~min}$. after the addition of E 600 an undetectable amount of inhibitor remained; for dimethyl $p$-nitrophenyl phosphate $40 \mathrm{~min}$. were 


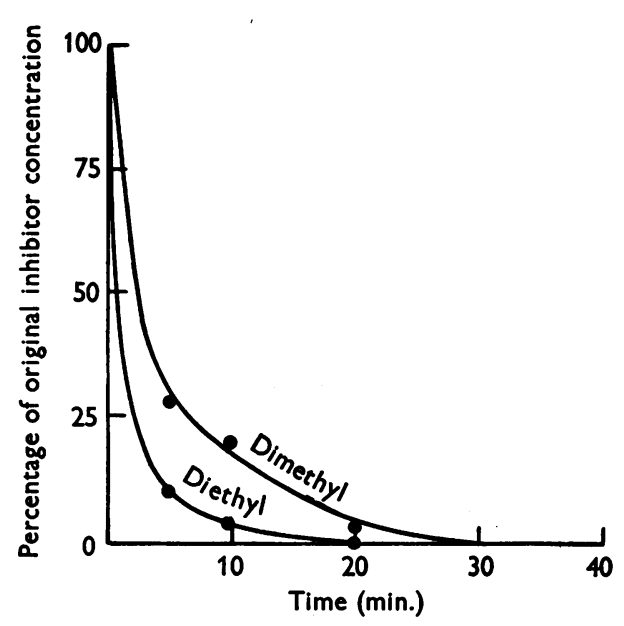

Fig. 2. Removal of dimethyl and diethyl $p$-nitrophenyl phosphates by whole rabbit blood. Initial concentrations of inhibitor: dimethyl, $2.5 \times 10^{-6} \mathrm{M}$; diethyl, $3.4 \times 10^{-7} \mathrm{M}$. Concentration of rabbit blood as in Fig. 1. After various times of incubation a sample was cooled in ice, centrifuged and $3.0 \mathrm{ml}$. of supernatant added to $0.5 \mathrm{ml}$. washed rabbit erythrocytes. The inhibition of the erythrocyte cholinesterase was referred to a curve relating inhibitor concentration to inhibition prepared under identical conditions. Controls were carried out to determine cholinesterase in the supernatant. Buffer used contained $\mathrm{NaCl}$ and $\mathrm{NaHCO}_{3}$.

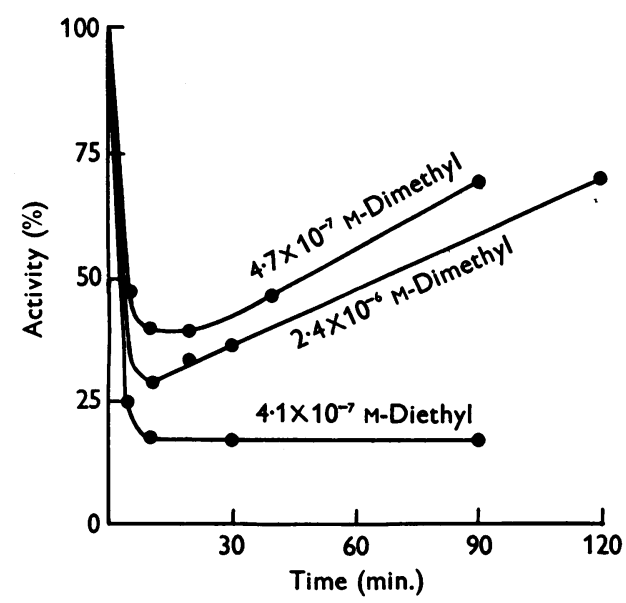

Fig. 3. The inhibition of cholinesterase of whole rabbit blood by dimethyl and diethyl $p$-nitrophenyl phosphates. Whole rabbit blood $(0.5 \mathrm{ml}$.) incubated with inhibitor and the substrate, acetylcholine, tipped in at various times. The activity is the mean output of $\mathrm{CO}_{2} / \mathrm{min}$. over the 10-30 min. period, readings' being taken every $5 \mathrm{~min}$. Concentrations of inhibitors shown against each curve. Buffer used contained $\mathrm{NaCl}$ and $\mathrm{NaHCO}_{3}$. required. The concentrations used for these experiments are the highest for any inhibition experiments and these times may be taken as a maximum for which any detectable amount of free inhibitor will be present. When E600 is added to rabbit whole blood, the cholinesterase inhibition rapidly reaches a maximum and then remains unaltered (Fig. 3). This is in agreement with the irreversible nature of the inhibition of cholinesterase by E600 demonstrated by other experimental techniques (Aldridge, 1950). On the other hand, when dimethyl $p$-nitrophenyl phosphate is added to rabbit whole blood, the inhibition also rapidly

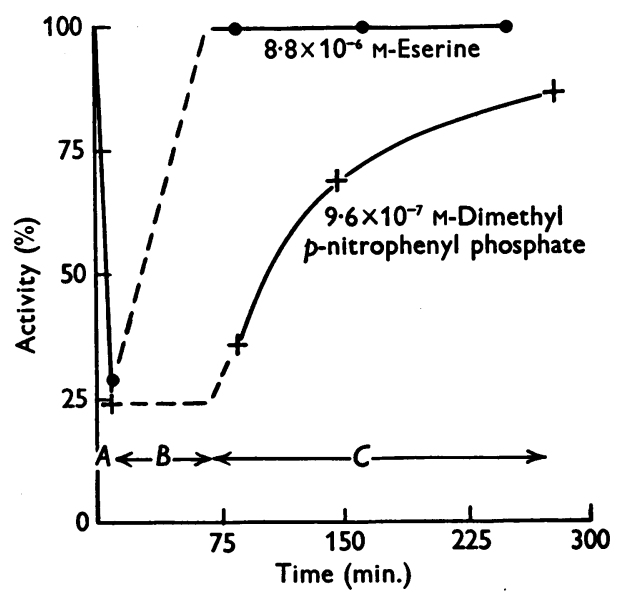

Fig. 4. Inhibition of rabbit erythrocytes cholinesterase by eserine and dimethyl $p$-nitrophenyl phosphate. $(A)$ Washed cells incubated with inhibitors for $10 \mathrm{~min}$. at $37^{\circ}$. $(B)$ Incubation mixture cooled to $0^{\circ}$, washed five times with ice-cold buffer and centrifuged at $0^{\circ}$. $(C)$ Cell suspension pipetted into Warburg vessels at $37^{\circ}$ and cholinesterase activity determined after various times of incubation. The activity of some washed cells from $(B)$ kept at $0^{\circ}$ for $270 \mathrm{~min}$. changed from 25 to $32 \%$. Concentration of inhibitors shown against each curve. Buffer used contained $\mathrm{NaCl}, \mathrm{NaHCO}_{3}$ and $\mathrm{MgCl}_{2}$.

reaches a maximum but after $20 \mathrm{~min}$. there is a slow return of enzyme activity (Fig. 3). After $40 \mathrm{~min}$., when there is an undetectable amount of free inhibitor present (Fig. 2), the cholinesterase is still $60 \%$ inhibited and the activity only slowly returns over several hours. The results of the experiments using dimethyl $p$-nitrophenyl phosphate with rabbit whole blood and washed erythrocytes could be interpreted on the basis of dimethyl $p$-nitrophenyl phosphate being a reversible inhibitor and the reversal process being a removal of the intact inhibitor molecule from the active centre.

$A$ comparison of the reversal of inhibition of cholinesterase by eserine and dimethyl p-nitrophenyl phosphate. If erythrocytes are inhibited by eserine and then washed with saline at $0^{\circ}$ the inhibition is 
readily reversed (Fig. 4). However, the cholinesterase activity of erythrocytes inhibited by dimethyl $p$-nitrophenyl phosphate is unchanged by washing at $0^{\circ}$, although, if these inhibited erythrocytes (now washed free from inhibitor) are warmed up to $37^{\circ}$ cholinesterase activity reappears (Fig. 4). This marked difference in behaviour after treatment with eserine and with dimethyl $p$-nitrophenyl phosphate suggests that the mechanisms of inhibition are different. The fact that the inhibition after dimethyl $p$-nitrophenyl phosphate is not removed by washing suggests that the washing itself plays no part in the reversal, i.e. the inhibition is not reversed simply by lowering the concentration

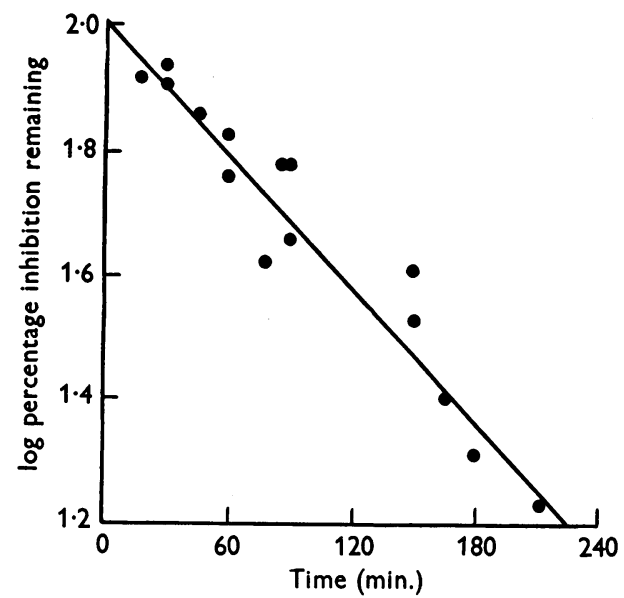

Fig. 5. Rate of reversal of inhibition of rabbit erythrocyte cholinesterase by dimethyl $p$-nitrophenyl phosphate. In some experiments inhibitor was added to whole blood directly, in others to washed erythrocytes and the excess inhibitor removed either by washing at $0^{\circ}$ or by adding a preparation of rabbit serum free from cholinesterase activity. The line shown is the best straight line calculated by the method of least squares.

of inhibitor in the suspending fluid. The fact that reversal does take place when these same cells are warmed to $37^{\circ}$ suggests that temperature is the factor involved and the reversal mechanism has a high temperature coefficient. Such a coefficient is consistent with a chemical reaction and not with a desorption process.

Kinetics of reversal of the inhibition of cholinesterase by dimethyl p-nitrophenyl phosphate. The results of various experiments carried out to determine the rate of reversal of inhibition after dimethyl $p$-nitrophenyl phosphate are given in Fig. 5. In some experiments inhibitor was added to whole blood directly and in others to washed erythrocytes, and the excess inhibitor was removed either by addition of an A-esterase preparation or by washing at $0^{\circ}$. In Fig. $5, \log _{10}$ (percentage of total inhibition remaining) is plotted against time. The points fall about a straight line and indicate that the kinetics of reaction are first order. An appreciable scatter is to be expected since all the inhibition values are difference values between the original and final enzyme activities. The first-order constant calculated from these results is $8.7 \times 10^{-3}\left(\mathrm{~min} .^{-1}\right)$.

It has previously been shown that the rate of the reversal reaction is less when the temperature is lowered. The first-order velocity constants of the reversal process have been determined at three temperatures. From these results the energy of activation has been calculated using Arrhenius's equation (Table 4). The value of this constant is $14400 \mathrm{cal}$./mole. The energy of activation of the hydrolysis of the inhibitor, dimethyl E600, in

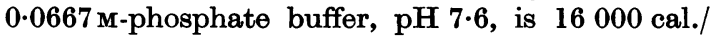
mole. The high value for the energy of activation of the reversal reaction is not consistent with the inhibition being a simple absorption process.

Table 4. Effect of temperature on the rate of reversal of the inhibition of rabbit erythrocyte cholinesterase caused by dimethyl p-nitrophenyl phosphate and on the rate of aqueous hydrolysis of dimethyl p-nitrophenyl phosphate

(Washed rabbit erythrocytes were treated at $37^{\circ}$ with inhibitors and then with a rabbit-serum preparation free from cholinesterase to remove excess inhibitor. The enzyme activity was determined after incubation for various times at different temperatures. The concentration of $\mathrm{NaHCO}_{3}$ necessary to maintain the $\mathrm{pH}$ at $\mathbf{7 . 7 8}$ after gassing with $5 \% \mathrm{CO}_{2}$ in $\mathrm{N}_{2}$ at different temperatures was calculated from the Henderson-Hasselbach equation. The concentrations used were at $17^{\circ}, 0.077 \mathrm{M} ; 28^{\circ}, 0.0488 \mathrm{M} ; 37^{\circ}, 0.0357 \mathrm{M}$. The rate of hydrolysis of dimethyl $p$-nitrophenyl phosphate was determined in Sørensen's 0.0667 M-phosphate buffer, pH 7.6. The liberated $p$-nitrophenol was determined colorimetrically using the Unicam quartz spectrophotometer. The temperature coefficient of Sørensen's phosphate buffer was taken as zero.)

$\begin{array}{ccc}\begin{array}{c}\text { Temperature } \\ \left({ }^{\circ}\right)\end{array} & \begin{array}{c}\text { First-order } \\ \text { rate constant } \\ \left(\text { min. }{ }^{-1}\right)\end{array} & \begin{array}{c}\text { Energy of } \\ \text { activation } \\ \text { (cal./mole) }\end{array} \\ \begin{array}{c}\text { Reversal of inhibition } \\ 17\end{array} & \\ 28 & \begin{array}{c}1.68 \times 10^{-3} \\ 4.29 \times 10^{-3} \\ 37\end{array} & 8.55 \times 10^{-3}\end{array}$

Hydrolysis of dimethyl $p$-nitrophenyl phosphate

$$
\left(\mathrm{hr}^{-1}\right. \text { ) }
$$

$15 \cdot 8 \quad 2.37 \times 10^{-8}$

$26.3 \quad 6.18 \times 10^{-3}$

$36.7 \quad 1.53 \times 10^{-2}$

16000

Effect of temperature on inhibition of cholinesterase by $E$ 600. In a previous paper (Aldridge, 1953b) it was suggested that cholinesterase catalyses the hydrolysis of the inhibitors in the same way as it catalyses the hydrolysis of other esters, the enzyme being inhibited because one of the products remains 
Table 5. Effect of temperature on the rate of inhibition of rabbit erythrocyte cholinesterase by $E 600$ and on the rate of aqueous hydrolysis of $E 600$

(Washed rabbit erythrocytes were incubated with E600 at different temperatures. The enzyme activity was determined at the same temperatures after various times of incubation. The concentration of $\mathrm{NaHCO}_{3}$ necessary to maintain the $\mathrm{pH}$ at 7.78 after gassing with $5 \% \mathrm{CO}_{2}$ in $\mathrm{N}_{2}$ at different temperatures was calculated from the HendersonHasselbach equation. The concentrations used were at $19^{\circ}$, $0.0707 \mathrm{M}$; at $28^{\circ}, 0.0488 \mathrm{M}$; at $37^{\circ}, 0.0357 \mathrm{M}$. The rate of hydrolysis of E600 was determined in Sørensen's 0.0667 M-

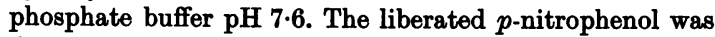
determined colorimetrically using the Unicam quartz spectrophotometer. The temperature coefficient of Sørensen's phosphate buffer was taken as zero.)

\begin{tabular}{|c|c|c|}
\hline \multicolumn{3}{|c|}{ Hydrolysis of E600 } \\
\hline $\begin{array}{l}\text { Temperature } \\
\left(^{\circ}\right)\end{array}$ & $\begin{array}{l}\text { First-order } \\
\text { rate constant } \\
\left(\mathrm{hr}^{-1}\right)\end{array}$ & $\begin{array}{l}\text { Energy of } \\
\text { activation } \\
\text { (cal./mole) }\end{array}$ \\
\hline $\begin{array}{l}17 \cdot 6 \\
26 \cdot 5 \\
36 \cdot 7\end{array}$ & $\left.\begin{array}{l}3.91 \times 10^{-4} \\
1.00 \times 10^{-3} \\
2.88 \times 10^{-3}\end{array}\right\}$ & 18500 \\
\hline \multicolumn{3}{|c|}{ Inhibition of cholinesterase by $\mathbf{E} 600$} \\
\hline $\begin{array}{l}\text { emperature } \\
\left(^{\circ}\right)\end{array}$ & $\begin{array}{c}\text { Bimolecular } \\
\text { rate constant } \\
\left(\text { min. }^{-1} \text { l. mol. }\right. \\
\text {-1) }\end{array}$ & $\begin{array}{l}\text { Energy of } \\
\text { activation } \\
\text { (cal./mole) }\end{array}$ \\
\hline $\begin{array}{l}19 \cdot 2 \\
28 \\
37\end{array}$ & $\left.\begin{array}{l}8.91 \times 10^{5} \\
1.58 \times 10^{8} \\
2.58 \times 10^{8}\end{array}\right\}$ & 10600 \\
\hline
\end{tabular}

attached. With this in mind, the rate of inhibition of whole rabbit erythrocytes by $\mathrm{E} 600$ has been determined at different temperatures. The inhibition at all the temperatures is first order. From the bimolecular rate constants for this reaction at different temperatures the energy of activation is $10600 \mathrm{cal} . / \mathrm{mole}$ (Table 5). The energy of activation for the aqueous hydrolysis of $\mathrm{E} 600$ in $0.0667 \mathrm{M}$ phosphate buffer $\mathrm{pH} \mathrm{7.6}$ is 18500 . It is clear that the inhibitory process is a chemical reaction and not a simple adsorption.

\section{DISCUSSION}

Mammalian cholinesterase has not been obtained in a pure state and for this reason the mechanism of its inhibition by organophosphorus compounds cannot be examined by the direct methods which have been used with chymotrypsin. For crystalline chymotrypsin the inhibitory process consists of the dialkylphosphorylation of the enzyme with the liberation of one mole of acid per mole of enzyme inhibited. This process has been demonstrated for DFP by Jansen, Fellowes-Nutting, Jang \& Balls (1950), for TEPP by Fleischer, Jandorf, Summerson \& Norton (1950) and for E 600 by Hartley \& Kilby (1952). Schaffer, May \& Summerson (1952) have shown that crystalline DFP-inhibited chymotrypsin yields serine phosphoric acid after degradation with enzymes and acid. In the discussion to follow the properties of the reaction of organophosphorus compounds with cholinesterase will be examined.

Reaction of organophosphorus compounds with enzymes other than chymotrypsin. It is becoming clear that the organophosphorus compounds are general inhibitors for enzymes possessing carboxylicesterase activity. In Table 6 is given a list of six enzymes which have been shown to be inhibited by a variety of such compounds. One exception, Aesterase, which hydrolyses aromatic carboxylic

Table 6. Organophosphorus compounds as general inhibitors for enzymes having carboxylic esterase activity

Enzyme
Chymotrypsin
Trypsin

Cholinesterase, true
and pseudo
Liver esterase and
milk lipase
Acetyl esterase
(orange and wheat)
B-esterase

Inhibitor

Diphenyl phosphonochloridate Diethyl phosphorofluoridothionate Tetraisopropyl pyrophosphate Tetrapropyl dithionopyrophosphate Tetraethyl pyrophosphate

Diethyl $p$-nitrophenyl phosphate

Diisopropyl phosphonofluoridate Tetraethyl pyrophosphate

Diethyl $p$-nitrophenyl phosphate and OS-diethyl $O$-p-nitrophenyl phosphorothiolate

Diisopropyl phosphonofluoridate

Diisopropyl phosphonofluoridate and analogues

11 organophosphorus compounds

Diisopropyl phosphonofluoridate

Reference

Jansen, Fellowes-Nutting, Jang \& Balls (1949)

Jansen, Curl \& Balls (1951)

Jansen, Fellowes-Nutting, Jang \& Balls (1950)

Hartley \& Kilby (1950)

Jansen \& Balls (1952) -

Jansen, Fellowes-Nutting,

Jang \& Balls (1950)

Kilby \& Youatt (1952)

Mazur \& Bodansky (1946)

Mackworth \& Webb (1948)

Aldridge (1953 $b$ )

Webb (1948)

Tetraethyl pyrophosphate

Diisopropyl phosphonofluoridate

Tetraethyl pyrophosphate, diisopropyl phosphonofluoridate and diethyl $p$-nitrophenyl phosphate
Jansen, Fellowes-Nutting

\& Balls (1948)

Aldridge (1953c) 
esters has been reported (Aldridge, 1953a). It has been shown that the reactions with organophosphorus compounds of the six enzymes listed in Table 6 follow first-order kinetics and are bimolecular. After inhibition of chymotrypsin with DFP the crystalline inhibited enzyme contains phosphorus. Several workers have also shown that various cholinesterases after inhibition with DFP containing ${ }^{32} \mathrm{P}$ do contain phosphorus firmly bound to the enzyme (Boursnell \& Webb, 1949; Michel \& Krop, 1951; Michel, 1952; Jansen, Jang \& Balls, 1952). It therefore seems likely that the inhibitory process with cholinesterase is similar to that with chymotrypsin.

Kinetics of inhibition and reversal of inhibition of cholinesterase. When precautions are taken that the compounds which are inhibitors contain an anhydride-like structure and Aldridge \& Davison $(1952 a, b)$ have demonstrated that amongst a series of analogues of E 600 the more unstable they are to hydrolysis the more efficient they are as inhibitors. In other words, the efficiency of members of such an homologous series in phosphorylating water parallels their ability to inhibit cholinesterase (Topley, 1950).

These findings support the phosphorylation theory of the inhibition of cholinesterase. On the basis of the evidence discussed above it is possible to suggest the following reaction mechanism for the inhibition and reversal of inhibition of cholinesterase by symmetrical dialkyl aryl phosphates

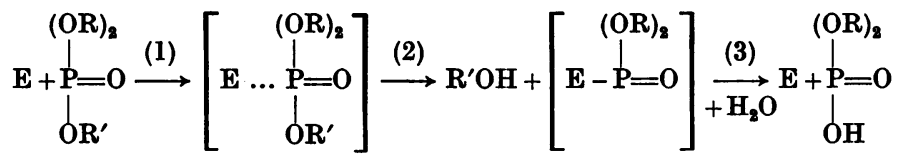

( $\mathbf{E}=$ cholinesterase; $\mathbf{R}=$ alkyl; $\mathbf{R}^{\prime}=$ aryl.)

It is interesting to compare a similar diagrammatic representation of the reaction mechanism for the hydrolysis of acetylcholine by cholinesterase postulated by Wilson et al. (1950).

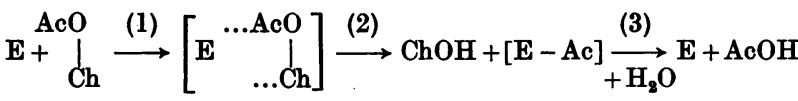

$$
\begin{aligned}
& \text { (AcO- } \mathrm{Ch}=\text { acetylcholine; } \mathrm{ChOH}=\text { choline; } \mathrm{AcOH}=\text { acetic acid.) }
\end{aligned}
$$

inhibitor is not removed by reactions other than that with the enzyme, the inhibitory process is progressive and does not reach an equilibrium quickly. The inhibited enzyme so produced, after removal of the inhibitor, is in many cases extremely stable and the enzyme activity returns only slowly. The inhibition produced by DFP is reversed more slowly than that produced by TEPP or E 600. In this paper the recovery of activity after dimethyl $p$-nitrophenyl phosphate has been shown to take place much more rapidly than after E600. Such processes which go slowly to completion are typically chemical reactions rather than simple adsorptive processes which reach equilibrium quickly. The same conclusion is suggested by the high temperature coefficients of both the inhibitory process and the recovery of enzyme activity. When the cholinesterase of intact erythrocytes after inhibition by eserine is washed at $0^{\circ}$ the original enzyme activity is recovered. However, treatment of erythrocytes by dimethyl $p$-nitrophenyl phosphate inhibited in the same way results in little or no return of activity.

The 'phosphorylation theory'. Both the comparison with the reaction of chymotrypsin with organophosphorus compounds and the kinetics of their reaction with cholinesterase are consistent with the view that the inhibitor phosphorylates the enzyme. Brauer (1948) pointed out that organophosphorus
On this view the inhibition of cholinesterase by organophosphorus compounds and the hydrolysis of acetylcholine by cholinesterase are closely analogous reactions. Just as marked changes are produced in the rates of hydrolysis of choline esters by changes in the length and shape of the aryl groups, so alterations in the length and shape of the alkoxy groups of organophosphorus compounds produce corresponding changes in their inhibitory powers against true and pseudo-cholinesterase (Aldridge, 1953b). It has been pointed out by Wilson et al. (1950) that the rate-determining step is the formation of the acylated enzyme while reaction (3) must be comparatively fast. In a similar scheme shown for the inhibitory process, the ratelimiting step is reaction (3), thus allowing the accumulation of the inhibited enzyme by reactions (1) and (2). If reaction (3) were fast compared with reactions (1) and (2), then the enzyme would not be inhibited and the organophosphorus compound would be rapidly hydrolysed. It is interesting that enzymes which hydrolyse DFP and E 600 have been reported (Mazur, 1946; Aldridge, $1953 a$ ). However, these hydrolyses may be mediated by different reaction mechanisms.

Briefly, the experimental results obtained by many workers are consistent with the view that since organophosphorus inhibitors are esters, they can attach themselves to the active centre of cholin- 
esterase in the same way as carboxylic esters; the inhibitor is then hydrolysed but the enzyme remains phosphorylated instead of both products passing into solution. The enzyme phosphate so formed has its own stability to hydrolysis and this is dependent upon the groups attached to the phosphorus atom. On such a hypothesis the potency of these inhibitors is a reflexion not of an especially high affinity for the enzyme but of the fact that one active centre is inactivated after reaction with one inhibitor molecule. Conclusive proof of this mechanism must await a considerable purification of cholinesterase and the identification of the products liberated at the various stages of the reaction.

\section{SUMMARY}

1. The inhibition of erythrocyte cholinesterase by dimethyl $p$-nitrophenyl phosphate reverses at a measurable rate.
2. Some properties of the reversal process have been examined.

3. The effect of temperature on the reversal process has been determined. The energy of activation calculated from these results indicates that the reversal process is a chemical reaction.

4. The effect of temperature on the inhibitory reaction of diethyl $p$-nitrophenyl phosphate with rabbit-erythrocyte cholinesterase has been determined.

5. These results and those of other workers have been discussed and a mechanism for inhibition and reversal suggested.

I am grateful to Miss J. E. Cremer for valuable technical assistance, to Dr H. Coates (Albright and Wilson Ltd.) for the samples of dimethyl, diethyl and diisopropyl $p$-nitrophenyl phosphates and to Allen and Hanbury Ltd. for the diisopropyl phosphonofluoridate.

\section{REFERENCES}

Aldridge, W. N. (1950). Biochem. J. 46, 451.

Aldridge, W. N. (1953a). Biochem. J. 53, 117.

Aldridge, W. N. $(1953 b)$. Biochem. J. 53, 62.

Aldridge, W. N. (1953c). Biochem. J. 53, 110.

Aldridge, W. N., Berry, W. K. \& Davies, D. R. (1949). Nature, Lond., 164, 925.

Aldridge, W. N. \& Davison, A. N. (1952a). Biochem. J.51, 62.

Aldridge, W. N. \& Davison, A. N. (1952b). Biochem. J.52, . 663.

Boursnell, J. C. \& Webb, E. C. (1949). Nature, Lond., 164, 875.

Brauer, R. W. (1948). J. Pharmacol. 92, 162.

Burgen, A. S. V. \& Hobbiger, F. (1951). Brit. J. Pharmacol. 6, 593.

Callaway, S., Davies, D. R. \& Risley, J. E. (1952). Biochem. J. 50, xxx.

Dayrit, C., Manry, C. H. \& Seevens, M. H. (1948). J. Pharmacol. 92, 173.

Fleischer, J. H., Jandorf, B. J. \& Summerson, W. H. \& Norton, D. P. (1950). Fed. Proc. 9, 171.

Hartley, B. S. \& Kilby, B. A. (1950). Nature, Lond., 166, 784.

Hartley, B. S. \& Kilby, B. A. (1952). Biochem. J. 50, 672.

Hobbiger, F. (1951). Brit. J. Pharmacol. 6, 21.

Jansen, E. F. \& Balls, A. K. (1952). J. biol. Chem. 194, 721.
Jansen, E. F., Curl, A.L. \& Balls, A. K. (1951). J. biol. Chem. $190,557$.

Jansen, E. F., Fellowes-Nutting, M. D. \& Balls, A. K. (1948). J. biol. Chem. 175, 975.

Jansen, E. F., Fellowes-Nutting, M. D., Jang, R. \& Balls, A. K. (1949). J. biol. Chem. 179, 189.

Jansen, E. F., Fellowes-Nutting, M. D., Jang, R. \& Balls, A. K. (1950). J. biol. Chem. 185, 209.

Jansen, E. F., Jang, R. \& Balls, A. K. (1952). J.biol. Chem. 196, 247.

Kilby, B. A. \& Youatt, G. (1952). Biochim. biophys. Acta, 8, 112.

Levine, M. G., Hoyt, R. E. \& Suran, A. A. (1950). Proc. Soc. exp. Biol., N.Y., 73, 100.

Mackworth, J. F. \& Webb, E. C. (1948). Biochem. J. 42, 91. Mazur, A. (1946). J. biol. Chem. 164, 271.

Mazur, A. \& Bodansky, O. (1946). J. biol. Chem. 163, 261.

Mendel, B. \& Rudney, H. (1945). Science, 102, 616.

Michel, H. O. (1952). Fed. Proc. 11, 259.

Michel, H. O. \& Krop, S. (1951). J. biol. Chem. 190, 119.

Schaffer, N. K., May, S. C. \& Summerson, W. H. (1952). Fed. Proc. 11, 282.

Topley, B. (1950). Chem. \& Ind., p. S859.

Webb, E. C. (1948). Biochem. J. 43, 96.

Wilson, I. B. (1951). J. biol. Chem. 190, 111.

Wilson, I. B., Bergmann, F. \& Nachmansohn, D. (1950). J. biol. Chem. 186, 693. 